\title{
Carbon Paste Electrodes for Oxomemazine Hydrochloride: Fabrication and Evaluation
}

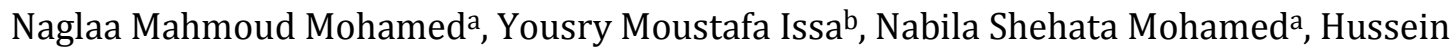

Shaban Mohamedc,*, Sayed Abdelkader Ahmed ${ }^{\mathrm{d}}$

${ }^{a}$ Environmental science and industrial development Department, Faculty of Postgraduate Studies for

Advanced Science, Beni-Suef University, Beni-Suef, Egypt

${ }^{b}$ Chemistry Department, Faculty of Science, Cairo University, Giza, Egypt

${ }^{c}$ Research institute of Medicinal and Aromatic plants, Beni-Suef University, Beni-suef, Egypt

${ }^{d}$ Chemistry Department, Faculty of Science, Beni-Suef University, Beni-suef, Egypt

\section{A R T I C L E I N F O}

Received: 8 May 2019

Revised: 7 June 2019

Accepted: 27 June 2019

Available online: 27 June 2019

DOI: $10.33945 /$ SAMI/AJCA.2020.1.4

\section{K E Y W O R D S}

Oxomemazine hydrochloride

Carbon paste electrodes

Oils

\section{A B S T R A C T}

The evaluation of oxomemazine hydrochloride (OXCl) prepared in carbon paste electrodes is reported in detail. There are many practical techniques and experiments for electrode preparation one of them is mixing of the ion-pair with ion pairing agent. Prepared electrodes gave satisfactory data in ranging from $(0.018$ to 18.35$) \mathrm{mg}$ based on Nernstian cationic slopes, the used electrodes refer to the standard data obtained at (slope $58.7 \pm 2.1 \mathrm{mV}$ decade $^{-1}$ ) by using sodium tetraphenylborate (NaTPB) and rapid response time equal to $15 \mathrm{~s}$ and lifetime approximately equal to ( 4 weeks). The prepared electrodes can be counted as end point indicator electrode for potentiometric titration of oxomemazine Hydrochloride $\mathrm{OXCl}$ resulting in a high percentage of accuracy.

GRA P H I CAL ABSTRACT

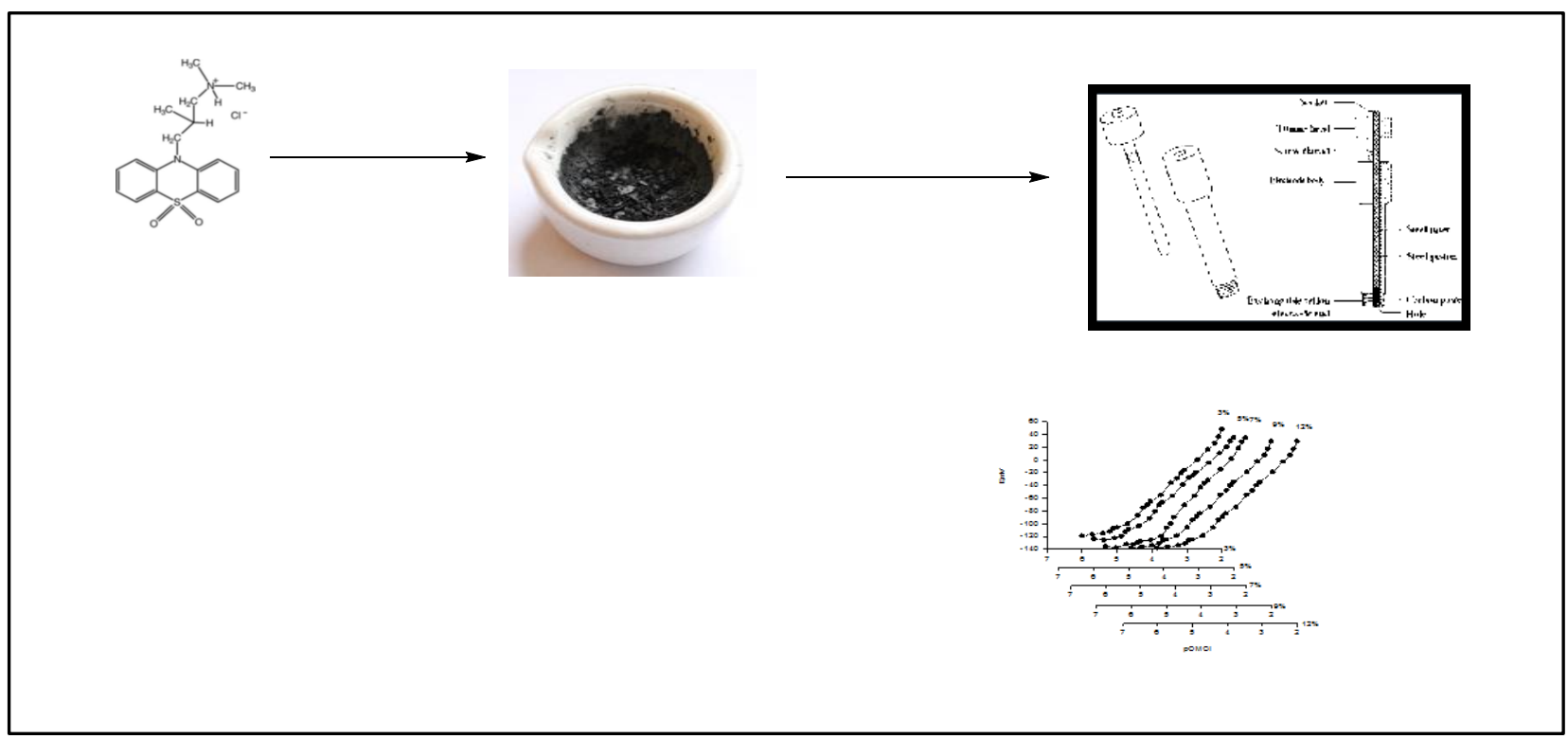

* Corresponding author's E-mail address: h_gendy_2010@yahoo.com 


\section{Introduction}

Oxomemazine, a phenothiazine group, is regarded as a drug which is very significant, owing to its connection to hypersensitivity is deemed an important drug helping patients which suffer from cough, also common cold. Drug can be taken by several ways for the patients orally, rectally by using suppositories on a daily basis and precautions. Oxomemazine hydrochloride $(\mathrm{OXCl})$ chemically has the formula $[3-(5,5-$ dioxodo-10H-phenothiazin-10-yl)-N, N, 2trimethylpropan-1-amine] (Figure 1). Several techniques have been cited due to its general important characteristic studying, involving spectrophotometry $[2,3]$ and HPLC [4]. With regard to the quality control, drug is utilized in necessary pharmaceutical industry with the aim of analyzing the starting materials, and finalized products.

ISEs ion selective electrodes counting up on a film, which is helpful in potentiometric measurements of activity of some ions by the means of other ions in the sample solution. Currently, ISEs ion selective electrodes exert a necessary role in measurements of solubility products of many economically soluble salts. Despite the progress of highly selective electrodes for various ions, no reference to progress of sensitive sensors for oxomemazine was reported [5,6].

The present study seeks to design and evaluate simple and easy sensors for rapid measurements of Oxomemazine OX. The obtained sensors were utilized as indicator electrode for potentiometric titration of Oxomemazine OX [7]. We used natural plasticizers in our study and this is due to low cost, more sensitive and safer for treatment of patients by drugs including them especially which suffers from liver and kidney diseases

\section{Experimental}

\section{Material and methods}

Oxomemazine hydrochloride Mwt, 366.91) and its pharmaceutical preparation were purchased by Egyptian Pharmaceutical Industries Company (Alexandria, Egypt), (NaTPB) $\mathrm{Na}\left[\mathrm{C}_{24} \mathrm{H}_{20} \mathrm{~B}\right]$ (Fluka), some natural plasticizers, polyvinylchloride (PVC), Tetrahydrofuran, Graphite powder 1-2 micron, some organic and inorganic cations were purchased from Aldrich chemical company. Other chemicals have been taken from Riedel de Haen Chemical Company.

\section{Apparatus}

Measurements were carried out by system consists of double junction electrode silver/silver chloride and connected by very sensitive amount of drug $[8,9]$.

The electrochemical system was as follows:

$\mathrm{Ag} / \mathrm{AgCl} /$ filling solution/membrane/test solution//KCl salt bridge//SCE.

\section{Results and discussion}

\section{Composition selection}

Preparation of matrices of compositions was done by mixing amounts of graphite, natural plasticizers, and ion-pair which represent sensing material. The components of the membrane represent a very important role in electrode response. Data concluded that the optimum compositions showing the best performance, for OM-TPB (oxomemazinesodium tetraphenylborate) attained up to $9 \%$ ion associate is $45.5 \%$ of graphite and $45.5 \%$ of plasticizer) in $18.34 \mathrm{mg} \mathrm{OMCl}$ as indicated in (Table 1).

\section{Plasticizer selection}

In the practical study, a group of natural plasticizers such as olive oil, corn oil and sun 
flower oil, which are more preferred due to their low cost, and very safety in comparison to other types were used variation of natural plasticizers provides us the best sensitive of them. The data shows that sun flower oil is the more favorable and higher sensitivity, owing to low solubility of OM-TPB (oxomemazine-sodium tetraphenylborate) ion exchange in those solvents (Table 2).

Table 1. Composition of oxomemazine carbon paste membrane electrodes and slopes of their corresponding calibration graphs at $25 \pm 1^{\circ} \mathrm{C}$ and $30 \mathrm{~min}$ of soaking

\begin{tabular}{|c|c|c|c|c|c|}
\hline \multirow{2}{*}{$\begin{array}{l}\text { OM-TPB oxomemazine sodium } \\
\text { tetraphenylborate } \\
\text { electrodes parameters } \\
\text { Ion associate }\end{array}$} & & Cor & osition \% & (w) & \\
\hline & 3 & 5 & 7 & 9 & 12 \\
\hline Graphite & 48.5 & 47.5 & 46.5 & 45.5 & 44.0 \\
\hline Sun flower oil & 48.5 & 47.5 & 46.5 & 45.5 & 44.0 \\
\hline Slope $\mathrm{mV} /$ decade & 51.2 & 52.3 & 58.5 & 58.7 & 47.0 \\
\hline RSD relative standard deviation \% & 1.56 & 1.79 & 0.89 & 2.86 & 3.50 \\
\hline \multirow[t]{2}{*}{ Linearity range (mg) } & $27.52-$ & $56.87-$ & 73.19- & $5.687-$ & $5.687-$ \\
\hline & 183.45 & 183.45 & 183.45 & 183.45 & 183.45 \\
\hline LOD limit of detection (mg) & 22.02 & 27.52 & 56.87 & 4.586 & 4.586 \\
\hline LOQ limit of Quantification (mg) & 73.19 & 91.54 & 1.16 & 1.50 & 0.150 \\
\hline Response time (s) & 8 & 8 & 8 & 8 & 8 \\
\hline
\end{tabular}

Table 2. Effect of plasticizers on oxomemazine carbon paste membrane electrodes and slopes of their corresponding calibration graphs at $25 \pm 1^{\circ} \mathrm{C}$ and $30 \mathrm{~min}$ soaking in $18.34 \mathrm{mg}$ of $\mathrm{OMCl}$ oxomemazine hydrochloride

\begin{tabular}{ccccc}
$\begin{array}{c}\text { OM-TPB oxomemazine sodium } \\
\text { tetraphenylborate }\end{array}$ & Pithout & Corn oil & Sun flower & Olive oil \\
& plasticizer & & oil & \\
Electrodes Parameters & 51.2 & 52.3 & 58.7 & 57.5 \\
Slope mV/decade & 1.79 & 1.22 & 1.96 & 2.46 \\
RSD relative standard deviation\% & $27.52-$ & $0.22-$ & $5.687-$ & $5.687-$ \\
Linearity range (mg) & 183.45 & 183.45 & 183.45 & 183.45 \\
& 0.22 & 27.52 & 0.0459 & 0.0459 \\
LOD limit of detection (mg) & 73.19 & 0.61 & 0.15 & 0.15 \\
LOQ limit of Quantification (mg) & 8 & 8 & 8 & 8 \\
Response time (s) & & & & \\
\hline
\end{tabular}




\section{Role of buffer}

Matrix of buffers such as phthalate, phosphate and acetate buffers which very important for standardization of the accuracy of electrode response and showed that phthalate, gives the highest slope compared to phosphate and acetate (Table 3 ). This showed the electrode enjoys a high degree of stability In contrast with the others.

\section{Following of soaking time}

Freshly electrodes produced were immersed consequently in different soaking solutions. These preconditioning different soaking solutions cause formation of a thin gel layer at membrane surface where ionexchange process can take place, also this conditions requires variations of soaking periods which related to wider spread and equilibrium beside interface. As reaching to that equilibrium definitely an ample indicator for excellent response. Significant characteristics of obtained electrodes were investigated in regarding to soaking times. For this purpose, obtained electrodes were studied and we concluded that soaking had effect on calibration curve by variation of times in independent way. For (OM-TPB) (oxomemazine-sodium tetraphenylborate) electrode, data obtained was revealed in (Table 4).

The life span of electrode is counting upon the adjectives of ion-exchanger; soaking electrodes for extended periods of time can decrease their response regarding drug action. This relates to filtering of mixture which formed ion-exchanger and plasticizer in solution. This is due to spread rates [1015].

\section{Response time consumed}

The response time can be defined as the time which passes through the instant at the moment at which an ion-selective electrode and a reference electrode became in connection with a sample solution, In accordance with this data indicating very short response time approximately $8 \mathrm{~s}$ referred to in (Figure 3).

Table 3. Effect of buffer on oxomemazine carbon paste membrane electrodes and slopes of their corresponding calibration graphs at $25 \pm 1{ }^{\circ} \mathrm{C}$ and $30 \mathrm{~min}$ soaking in $18.34 \mathrm{mg}$ of oxomemazine hydrochloride $\mathrm{OMCl}$

\begin{tabular}{cccc} 
OM-TPB oxomemazine sodium & & Buffer \\
tetraphenylborate electrodes & & Acetate & Phthalate \\
electrodes Parameters & Phosphate & 56.4 & 59.5 \\
Slope mV/decade & 57.8 & 1.79 & 1.68 \\
RSD relative standard deviation\% & 0.89 & $56.87-$ & $73.19-$ \\
Linearity range (mg) & $34.86-$ & 183.45 & 183.45 \\
& 183.45 & 45.86 & 56.87 \\
LOD limit of detection (mg) & 27.52 & 15.26 & 0.189 \\
LOQ limit of Quantification (mg) & 91.54 & 8 & 8 \\
Response time (s) & 8 & & \\
\hline
\end{tabular}


Table 4. Effect of soaking on sun flower oil carbon paste membrane electrodes at $25.0 \pm 1.0^{\circ} \mathrm{C}$

\begin{tabular}{cccccc}
$\begin{array}{c}\text { OM-TPB oxomemazine } \\
\text { sodium tetraphenylborate } \\
\text { electrodes }\end{array}$ & \multicolumn{5}{c}{ Soaking time } \\
$\begin{array}{c}\text { Electrodes Parameters } \\
\text { Slope mV/decade }\end{array}$ & $0.5-24 \mathrm{~h}$ & 2 days & 8 days & 21 days & 30 days \\
RSD relative standard & 59.7 & 59.7 & 58.5 & 56.4 & 50.9 \\
deviation\% & 1.22 & 1.79 & 0.86 & 1.45 & 1.43 \\
Linearity range (mg) & $73.19-$ & $73.19-$ & $0.459-$ & $27.52-$ & $56.87-$ \\
& 183.45 & $183.45-$ & 183.45 & 183.45 & 183.45 \\
LOD limit of detection (mg) & 56.87 & 34.86 & 34.86 & 0.22 & 0.459 \\
LOQ limit of Quantification & 0.24 & 1.16 & 1.16 & 73.19 & 15.26 \\
$\quad$ (mg) & & & & & 8 \\
Response time (s) & 8 & 8 & 8 & 8 & \\
\hline
\end{tabular}

Figure 1. The chemical structure of $\mathrm{OMCl}$ oxomemazine hydrochloride<smiles>CC(CN1c2ccccc2S(=O)(=O)c2ccccc21)C[N+](C)(C)[O-]</smiles>

a result of foundation of free Oxomemazine base in solution, leading to a descending in concentration of Oxomemazine cation: $\mathrm{a} \mathrm{pK}_{\mathrm{a}}=$ $10.6[16,17]$.

\section{Effect of temperature}

Evaluation of the electrodes thermal stability

Contieously thermal stability of the obtained Electrode was investigated from calibration graphs (Eelect. vs pdrug) at various test solution temperature which varies from 30 $70^{\circ} \mathrm{C}$. 
Figure 2. Calibration graphs using OM-TPB oxomemazinesodium tetraphenylborate) carbon paste electrode sun flower oil at different ion associate percentage

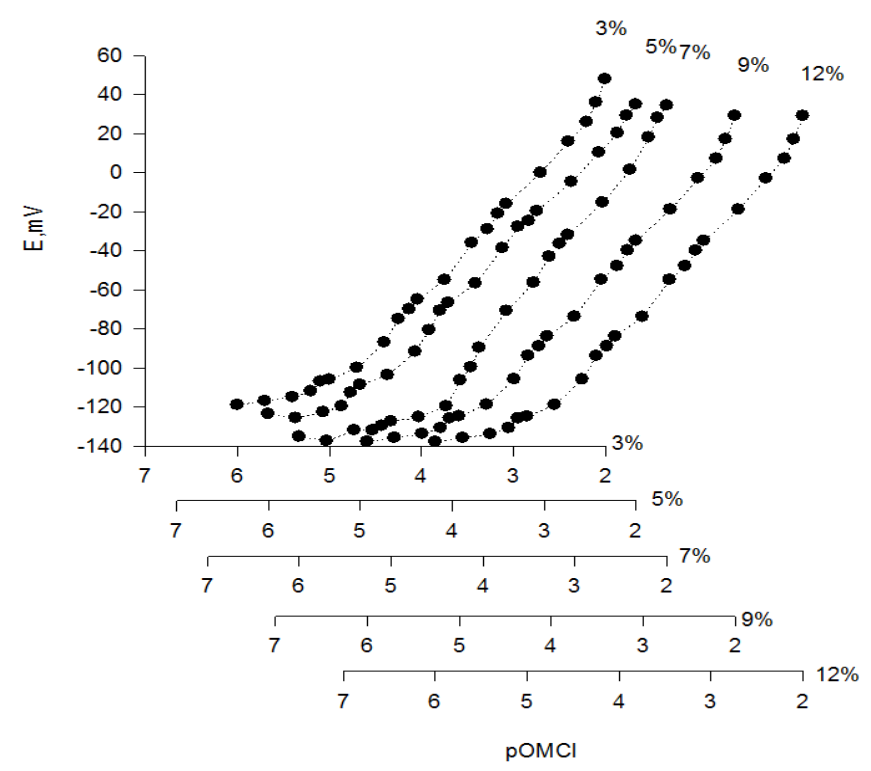

Figure 3. Potential-time plot for OM-TPB oxomemazinesodium tetraphenylborate sun flower oil carbon paste electrode

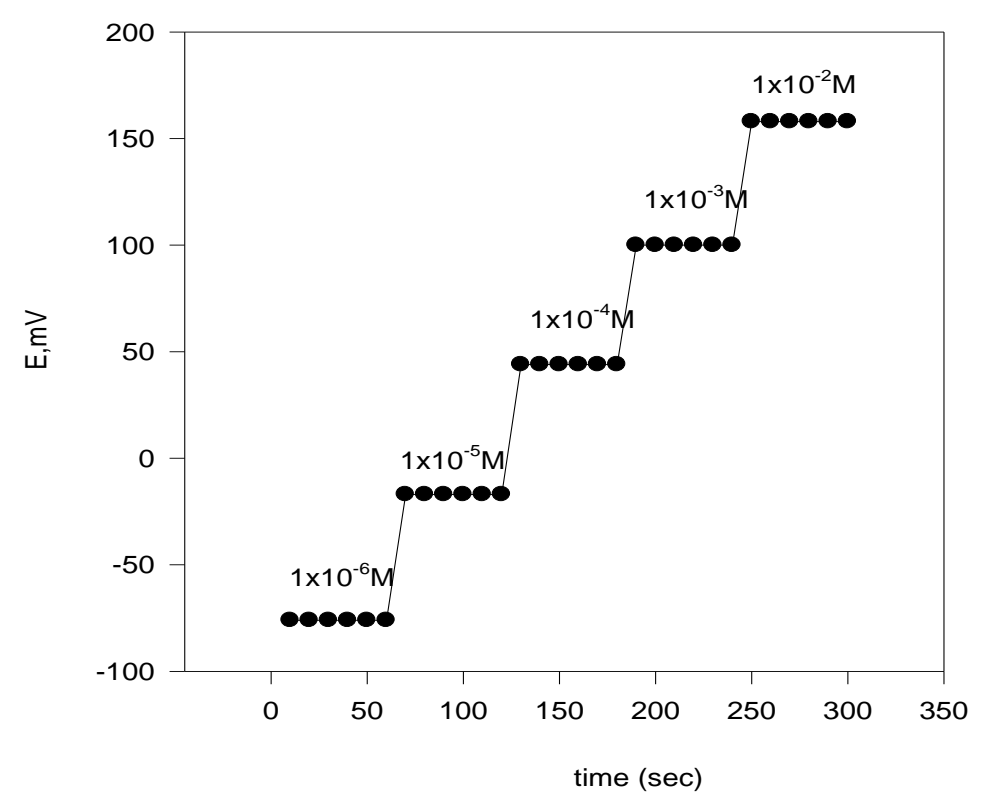

The data obtained are shown in (Table 5) which explain although the slopes are slightly increasing, still follows the Nernstian range despite the variation of temperature of test solutions until reaching to $70^{\circ} \mathrm{C}$.

Calculation of the isothermal coefficient of the prepared electrodes

In fact we note that the temperature of the test solution has a great relation with the potential of ion-selective electrodes. The electrode which enjoys by low thermal coefficient is considered achieving a high degree of thermal stability. This shows applicability of the electrode can be succeeded through a wide range of temperature. Based on calculating $\left(\mathrm{dE}^{\circ} / \mathrm{dt}\right)$ the cells, we must determine the standard cell potentials, $\mathrm{E}_{\text {cell, }}^{\circ}$ at various temperatures from the respective calibration plots as the intercept of these plots at $\mathrm{p}$ drug $=0$, knowing that $\mathrm{E}_{\text {cell }}^{\circ}$ is related to $\left(\mathrm{dE}^{\circ} / \mathrm{dt}\right)$ according to $[18,19]$. 


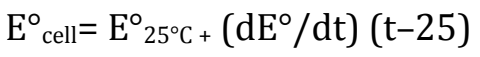

(1)

Plot of $\left(\mathrm{E}_{\text {cell }}^{\circ}\right)$ versus $(\mathrm{t}-25)$ produces straight line; the thermal coefficient of the cell can be obtained from the slope of this line. The standard potentials of electrodes ( $\mathrm{E}_{\text {elec. }}^{\circ}$ values can be measured after the subtraction of the standard electrodes potential of the calomel electrode at various temperatures severally; and this in turn reveals no difference from the theoretical Nernstian behavior.

Figure 4. Effect of $\mathrm{pH}$ of the test solution on the potential response using $\mathrm{OM}-\mathrm{TPB}$ oxomemazine-sodium tetraphenylborate sun flower oil carbon paste electrode

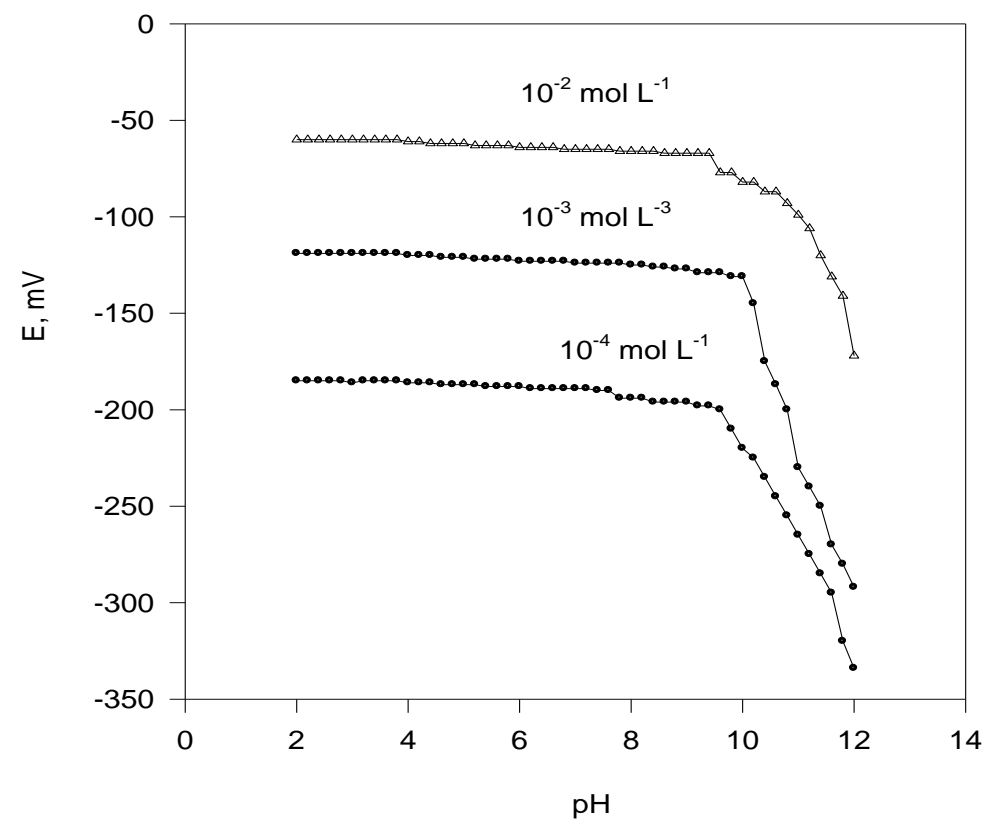

Table 5. Performance characteristics of oxomemazine carbon paste membrane sun flower oil electrodes at different temperatures

\begin{tabular}{cccccc}
$\begin{array}{c}\text { OM-TPB oxomemazine } \\
\text { sodium tetraphenylborate }\end{array}$ & \multicolumn{5}{c}{ Temperature ${ }^{\circ} \mathrm{C}$} \\
Electrodes Parameters & 30 & 40 & 50 & 60 & 70 \\
Slope mV/decade & 54.2 & 55.5 & 56.6 & 59.0 & 59.4 \\
RSD relative standard & 3.45 & 2.95 & 3.67 & 1.78 & 3.50 \\
deviation\% & & & & & \\
Linearity range (mg) & $22.02-183.45$ & $27.52-$ & $34.86-$ & $73.19-$ & 73.191. \\
& & 183.45 & 183.45 & 183.45 & 183.45 \\
LOD limit of detection (mg) & 0.18 & 22.02 & 27.52 & 56.87 & 56.87 \\
LOQ limit of Quantification & 0.61 & 73.19 & 91.54 & 1.89 & 18.93 \\
$\quad$ (mg) & & & & & \\
E cell the standard cell & 180 & 190 & 200 & 210 & 220 \\
potentials, mV & & & & & \\
Response time (s) & 8 & 8 & 8 & 8 & \\
\hline
\end{tabular}




\section{Selectivity measurements}

The selectivity of the examined electrodes under occurance of some cations can be investigated using matched potential method. The careful studying of selectivity is fundamental resource of information with regard to interference on the examined electrode response.

There was an investigation for the studying of the influence of variations of inorganic cations, amino acids and sugars. The results were shown in (Table 6).

For many years, the method of determination of degree of interference by means of selectivity coefficients of electrodes in potentiometric measurements was a subject of discussion in the literature [20]. Two specialized IUPAC committees were convened with regard to the measurements of potentiometric selectivity coefficients. In the first IUPAC committee held [21], separate solution method (SSM )was recommended only if the electrode exhibits Nernstian response, but it was favorable in comparison to fixed interference method (FIM); owing to the fact that it does not give the real conditions under which the electrodes are utilized. In 1995, the second IUPAC committee recommended matched potential method (MPM) for reporting selectivity coefficient which is independent of Nicolsky Eisenman equation [22].

The examined electrodes indicated on excellent behavior towards inorganic cations, amino acids and some sugars. This behavior can be explained due to inorganic cations don't interfere is that there are differences in ionic size, mobility and permeability. In cases of sugars, amino acids and vitamins, the high selectivity is fundamentally related to the difference in polarity and to the lipophilic nature of their molecules relative to oxomemazine hydrochloride $\mathrm{OMCl}$.

Analytical applications
Several methods were used in use for quantitative analysis using ion-selective electrodes. These include: (i) Direct calculation of the concentration applying Nernst equation. This method is subjected to several types of errors, e.g. $1 \mathrm{mV}$ shift in electrode potential reading results in $4 \mathrm{n} \%$ errors in which $\mathrm{n}$ is defined as the change of the ion. (ii) Potentiometric titration regarding the use of counter ion as titrant ion which is rather accurate depending fundamentally on using of ion selective electrode (ISE) for detecting end point detector. (iii) Standard addition method (SAM), which is frequently applied in using ISE.

\section{Potentiometric determinations applying the standard addition method SAM}

The Standard addition method (SAM, shown in the experimental part, was evidenced to be successful for Oxomemazine determination in pure solutions and in pharmaceutical preparations, via the prepared electrodes as sensors.

\section{Measurements of the drug in bulk and pharmaceutical analysis}

The standard addition method, described in the experimental part, was evidenced to be sufficient for measurements of (oxomemazine-sodium tetraphenylborate) OM-TPB in pure solutions via using the respective electrode as sensor. This is evident from the small relative standard deviation RSD values in ranges $(0.69-2.22 \%, 2.71$ $2.98 \%$ and $0.98-0.49$ ) for (Oxomemazinesodium tetraphenylborate) OM-TPB membrane (Table 7), which shows the high percentage of accuracy and precision of the electrodes $[5,6]$.

\section{Potentiometric titrations}

Although the fact that the measurements of concentration using potentiometric titration is time consuming, enjoys from the 
advantages as high percentage of accuracy and precision. Moreover, the calculation of the end point can be easily indicated by a sharp potential break; not to mention the utilization of partially exhausted electrode is possible and the exact potential value at the end point is of secondary interest [23].

The basic idea of this type of potentiometric titration is related to ionassociates formation. The titration process is influenced by several factors such as degree of completeness of the reaction, also the relation between the equilibrium constant of precipitation titration and the product solubility, i.e., the smaller solubility of product of the formed ion-exchanger, the sharper is the end point. As a result, the calculation of the solubility of product of the precipitate is of grand significance if a titration, which causes the formation of this precipitate, is under investigation. The reciprocity of the solubility product is nearly equivalent to the equilibrium constant of the precipitation reaction added to in the titration.

Table 6. Selectivity coefficients $-\log \mathrm{K}_{\mathrm{OM}, \mathrm{J}^{\mathrm{Z}}}^{\mathrm{pot}}$ for the OM sun flower oil electrodes

\begin{tabular}{|c|c|c|}
\hline \multirow[t]{2}{*}{ Interferent } & \multicolumn{2}{|c|}{ OM-TPB oxomemazine sodium tetraphenylborate } \\
\hline & SSM & MPM \\
\hline $\mathrm{Na}^{+}$ & 2.99 & 3.47 \\
\hline $\mathrm{K}^{+}$ & 2.21 & 2.68 \\
\hline $\mathrm{NH}_{4}+$ & 1.65 & 1.91 \\
\hline $\mathrm{Ca}^{2+}$ & 3.59 & 4.76 \\
\hline $\mathrm{Mg}^{2+}$ & 2.78 & 3.55 \\
\hline $\mathrm{Co}^{2+}$ & 3.57 & 4.30 \\
\hline $\mathrm{Zn}^{2+}$ & 3.48 & 4.78 \\
\hline $\mathrm{Ni}^{2+}$ & 3.44 & 3.98 \\
\hline $\mathrm{Sr}^{2+}$ & 3.68 & 2.88 \\
\hline $\mathrm{Ba}^{2+}$ & 4.26 & 4.38 \\
\hline $\mathrm{Fe}^{3+}$ & 3.55 & 4.40 \\
\hline $\mathrm{Cu}^{+2}$ & 3.95 & 2.76 \\
\hline $\mathrm{Cd}^{+2}$ & 4.25 & 4.55 \\
\hline Glucose & - & 2.40 \\
\hline Fructose & - & 2.18 \\
\hline Maltose & - & 3.25 \\
\hline Lactose & - & 2.36 \\
\hline Alanine & - & 4.37 \\
\hline Glycine & - & 2.28 \\
\hline Urea & - & 3.68 \\
\hline Ascorbic & - & 1.19 \\
\hline
\end{tabular}


Table 7. Determination of $\mathrm{OMCl}$ oxomemazine hydrochloride in pure solution and pharmaceutical preparations applying the standard addition method on $9 \%$ sun flower oil

\begin{tabular}{ccccc} 
Sample & \multicolumn{3}{c}{ Carbon paste membrane electrodes } \\
& $\begin{array}{c}\text { Taken } \\
\text { mg }\end{array}$ & $\begin{array}{c}\text { Found } \\
\text { mg }\end{array}$ & $\begin{array}{c}\text { Mean } \\
\text { Recovery } \%\end{array}$ & RSD \% \\
OM-TPB oxomemazine & 10.80 & 10.70 & 99.1 & 0.69 \\
sodium tetraphenylborate & 21.60 & 21.27 & 98.5 & 1.96 \\
pure solution & 32.40 & 32.56 & 100.5 & 2.50 \\
& 43.20 & 44.17 & 97.2 & 2.22 \\
Toplexile syrup & 32.72 & 32.55 & 99.5 & 2.71 \\
& 65.44 & 66.42 & 99.0 & 2.65 \\
Rectoplexile susppositotry & 98.16 & 97.00 & 98.9 & 2.98 \\
& 3.30 & 3.26 & 99.0 & 0.98 \\
& 6.60 & 6.43 & 97.5 & 0.76 \\
& 9.90 & 9.94 & 100.5 & 0.49 \\
\hline
\end{tabular}

Table 8. Determination of $\mathrm{OMCl}$ oxomemazine hydrochloride in pure solution applying potentiometric titrations method on $9 \%$ sun flower oil

\begin{tabular}{ccccc} 
Sample & \multicolumn{3}{c}{ Carbon paste membrane electrodes } \\
& Taken & Found & Mean & RSD \% \\
& mg & mg & Recovery \% & \\
OM-TPB oxomemazine sodium & 10.80 & 10.70 & 99.1 & 0.69 \\
tetraphenylborate pure solution & 21.60 & 21.27 & 98.5 & 1.96 \\
& 32.40 & 32.56 & 100.5 & 2.50 \\
Toplexile syrup & 43.20 & 44.17 & 97.2 & 2.22 \\
& 32.72 & 32.55 & 99.5 & 2.71 \\
Rectoplexile susppositotry & 65.44 & 66.42 & 99.0 & 2.65 \\
& 98.16 & 97.00 & 98.9 & 2.98 \\
& 3.30 & 3.26 & 99.0 & 0.98 \\
& 6.60 & 6.43 & 97.5 & 0.76 \\
\hline
\end{tabular}

Table 9. Critical response characteristics of carbon paste electrodes electroanalytical pramaters

\begin{tabular}{cc} 
Parameters & Value \\
Slope mV/decade & 58.7 \\
RSD relative standard deviation \% & 2.86 \\
Linearity range (mg) & $5.687-183.4$ \\
LOD limit of detection (mg) & 4.586 \\
LOQ limit of Quantification (mg) & 1.50 \\
PH range & $2-9.8$ \\
$\left(\mathrm{dE}^{\circ} / \mathrm{dt}\right)$ thermal coefficient electrode & $1.666 \times 10^{-3}$ \\
Response time (s) & 8 \\
Life time day & 30 min to 30 day \\
Recovery $\%$ & 99.1 \\
\hline
\end{tabular}


Furthermore, it has been indicated [24] that in a precipitation titration curve, the point with maximum slope may somewhat come before the equivalence point when the solubility product of the precipitate obtained is proportionally high. The (oxomemazinesodium tetraphenylborate) OM-PB electrodes were evidenced to be of much use for the measurements in pure solutions by potentiometric titration against standard solution of sodium tetraphenyl borate. Representative titration curves are indicated when, it is observed that when concentration of the drug is on increasing and, the inflection of the break point becomes sharper in comparison with the low drug concentration. Relative standard deviation RSD; besides the recovery values are referred to in Table 8 . Electroanalytical parameters of new carbon paste electrode showed in Table 9.

\section{Conclusion}

The present work has successfully indicated that the fabrication of oxomemazine carbon paste electrode OX-CPE electrode utilizes different preparation methods. The prepared electrodes showed Nernstian slopes in the concentration range 0.018 to $18.35 \mathrm{mg}$ with rapid response time (15 s), and long life span (4 weeks). The fabricated electrodes exert a significant role in its application for determination of end point indicator electrode for potentiometric titration of oxomemazine OX with NaTPB in the concentration ranging from 0.018 to $18.35 \mathrm{mg}$ with very good accuracy and sensitivity. Fabricated electrodes had shorter response time (10 s) compared to drug electrode.

\section{Aknowledgement}

We would like to thank all the subjects for their participation in the study.

\section{References}

[1]. G.G. Mohamed, T.A. Ali, M.F. El- Shahat, M. A. Migahed, A.M. Al-sabagh, Drug Test. Anal., 2012, 4, 1009-1013.

[2]. A.M. El-Didamony, M.A. Moustafa, Arab. J. Chem., 2010, 3, 265-270.

[3]. A.M. El-Didamony, Arch Pharm Chem. Life Sci., 2005, 338, 190-197.

[4]. G. Hoogewijs, D.L. Massart, J. Pharm. Biomed. Anal., 1984, 2, 449-463.

[5]. G. Horvai, E. Pungor, Crit. Rev. Anal. Chem. 1989, 21,1-28.

[6]. Y.H. Chu, C.C. Cheng, Cell. Mol. Life Sci. 1998, 54, 663-83.

[7]. Y.M. Issa, A.F. Shoukry, R.M. El-Nashar, J. Pharm. Biomed. Anal, 2001, 26, 379-386.

[8]. N.T. Abdel-Ghani, A.F. Shoukry, S.H. Hussein, J. Parm. Biomed. Anal., 2002, 30, 601611.

[9]. E. Khaled, H.N. Hassan, M.S. Kamel, B.N. Barsoum, Curr. Pharm. Anal., 2007, 3, 262267.

[10]. F. Faridbod, M. R. Ganjali, L. Safaraliee, S. Riahi, M. Hosseini, P. Norouzi, Int. J. Electrochem. Sci., 2009, 4, 1419.

[11]. F. Faridbod, M. R. Ganjali, B. Larijani , E. Nasli - Esfahani, S. Riahi, P. Norouzi, Int. J. Electrochem. Sci., 2010, 5, 880-894.

[12]. M.R. Ganjali, A. Alipour, S. Riahi, B. Larijani, P. Norouzi, Int. J. Electrochem. Sci., 2009, 4, 1262-1276.

[13]. M.R. Ganjali, F. Aboufazeli, S. Riahi, R. Dinarvand, p. Norouzi, M. H.Ghasemi, R kianiAnbuhiand, S. Meftah, Int. J. Electorchem. Sci., 2009, 4, 1138-1152.

[14]. S. Riahi, F. Faridbod, M. R. Ganjali, Sensor Lett., 2009, 7, 42-49.

[15]. S. Riahi, F. Faridbod, M. R. Ganjali, Sensor Lett., 2009, 15, 829-836.

[16]. U. Oesch, D. Ammann, W. Simon, Clin. Chem., 1986, 32, 1448-1459.

[17]. M.A. Elmonem, S.A. Abdulla, Res. J. Pharm. Biol. Chem. Sci., 2014, 5, 1113-1125. 
[18]. T.A. Ali, G.G. Mohamed, M.M.I. ElDessouky, S.M.A. El-Ella, R.T.F. Mohamed, Int. J. Electrochem. Sci., 2013, 8, 1469-1486.

[19]. R.A. Ammar, H. Otaif, A. Al-warthan, Int. J. Electrochem. Sci., 2012, 7, 2531-2542.

[20]. N.T. Abdel-Ghani, M.S. RizK, R.M. ElNashar, Analyst, 2000, 125, 1129-1133.

[21]. N.T. Abdel-Ghani, A.F. Shoukry, R.M. ElNashar, Analyst, 2001, 126, 79-85.

[22]. Y. Umezawa, K. Umezawa, K. Buhlmann, K. Tohda, S. Amemiya, Pure Appl. Chem., 2000, 72, 1851-2082.

[23]. M. Hirooka, A. Hiraoka, H. Ochi, Y. Koizumi, K. Michitaka, K. Joko, M. Abe, Y. Hiasa, J. Gastroenterol. Hepatol. 2019, 34, 567-74.

[24]. K. Vytras, J. Pharm. Biomed. Anal., 1989, 7, 789-812.

How to cite this manuscript: Naglaa M. Mohamed, Yousry Moustafa Issa, Nabila Shehata, Hussein S. Mohamed, Sayed A. Ahmed, Carbon Paste Electrodes for Oxomemazine Hydrochloride: Fabrication and Evaluation, Adv. J. Chem. A, 2020, 3(1), 24-35. 